\title{
What Is the Purpose of Education?
}

"The one continuing purpose of education, since ancient times, has been to bring people to as full a realization as possible of what it is to be a human being. Other statements of educational purpose have also been widely accepted: to develop the intellect, to serve social needs, to contribute to the economy, to create an effective work force, to prepare students for a job or career, to promote a particular social or political system. These purposes offered are undesirably limited in scope, and in some instances they conflict with the broad purpose I have indicated; they imply a distorted human existence. The broader humanistic purpose includes all of them, and goes beyond them, for it seeks to encompass all the dimensions of human experience." -Arthur W. Foshay, "The Curriculum Matrix: Transcendence and Mathematics, " Journal of Curriculum and Supervision, 1991

"[The purpose of education] has changed from that of producing a literate society to that of producing a learning society."

- Margaret Ammons, Associate Secretary of ASCD, "Purpose and Program: How Does Commitment Today Differ from That in Other Periods," Educational Leadership, October 1964
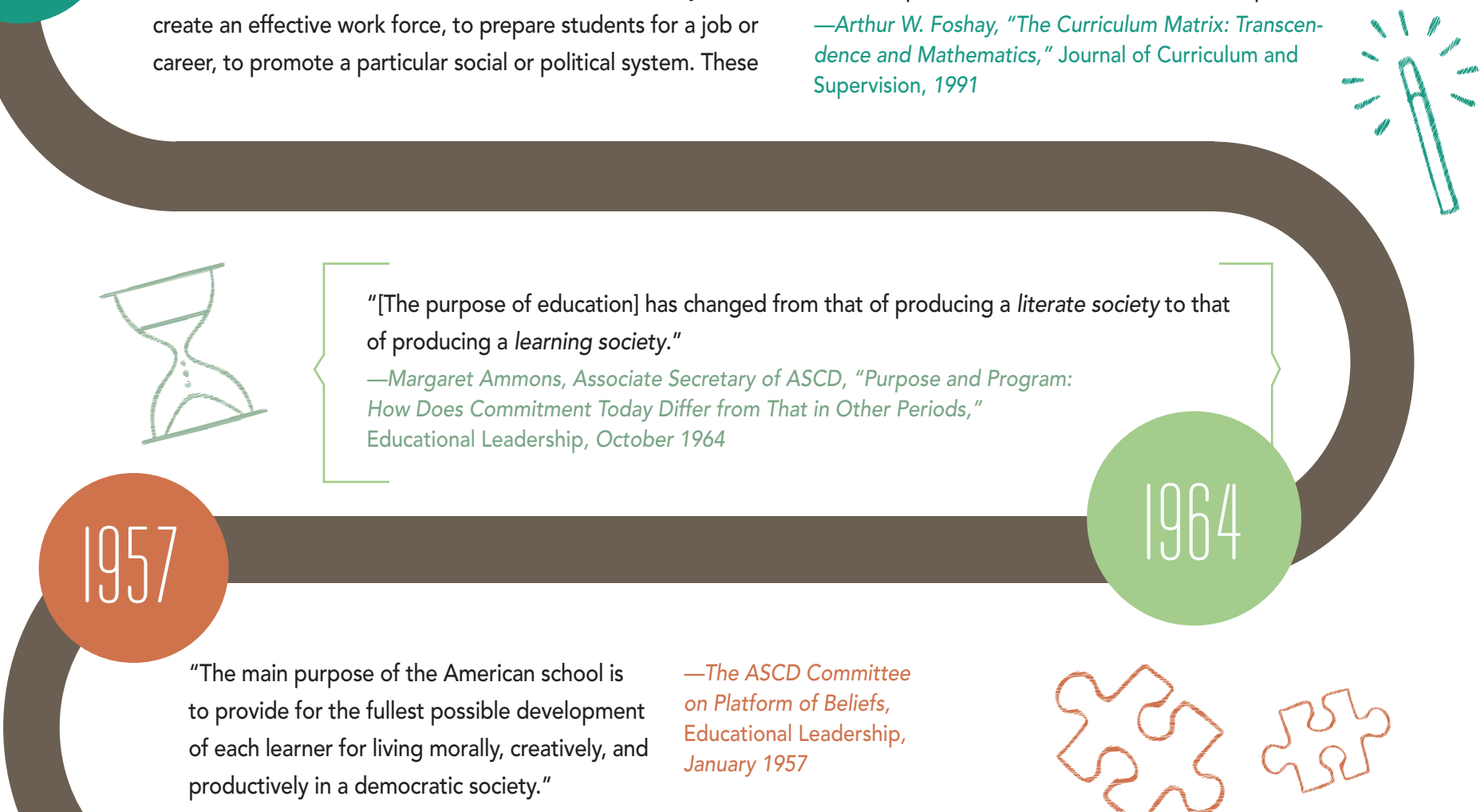
1964

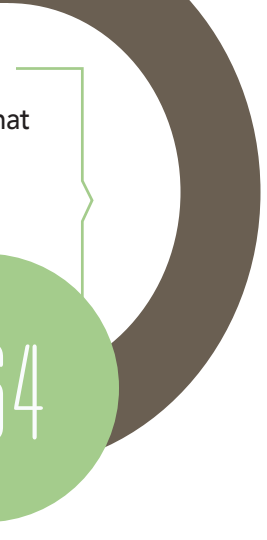

\begin{abstract}
- The ASCD Committee on Platform of Beliefs, Educational Leadership, January 1957 productively in a democratic society."

January 1957

"The main purpose of the American school is to provide for the fullest possible development
\end{abstract} productively in a democratic soclety."

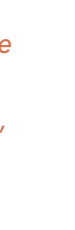

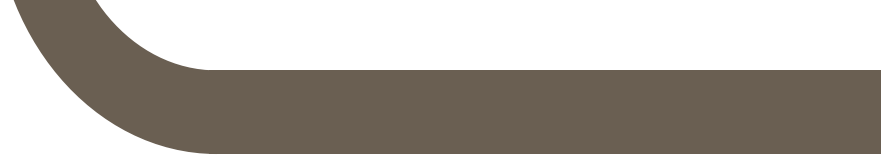

"The function of education is to teach one to think intensively and to think critically. But education which stops with efficiency may prove the greatest menace to society. The most dangerous criminal may be the man gifted with reason but no morals. ... We must remember that intelligence is not enough. Intelligence plus character-that is the goal of true education." -Martin Luther King Jr., speech at Morehouse College, 1948

"The purpose of education has always been to every one, in essence, the same- - to give the young the things they need in order to develop in an orderly, sequential way into members of society. This was the purpose of the education given to a little aboriginal in the Australian bush before the coming of the white man. It was the purpose of the education of youth in the golden age of Athens. It is the purpose of education today, whether this education goes on in a one-room school in the mountains of Tennessee or in the most advanced, progressive school in a radical community. But to develop into a member of society in the Australian bush had nothing in common with developing into a member of society in ancient Greece, and still less with what is needed today. Any education is, in its forms and methods, an outgrowth of the needs of the society in which it exists."

-John Dewey, "Individual Psychology and Education,"

The Philosopher, 12, 1934 